\title{
Physicochemical, Thermal, Structural, and Behavioral Properties Analysis in Magnesium Gluconate: An Effect of the Energy of Consciousness (The Trivedi Effect ${ }^{\circledR}$ )
}

\author{
Mahendra Kumar Trivedi ${ }^{1}$, Alice Branton ${ }^{1}$, Dahryn Trivedi ${ }^{1}$, Gopal Nayak ${ }^{1}$, \\ Cathryn Dawn Nykvist ${ }^{1}$, Celine Lavelle ${ }^{1}$, Daniel Paul Przybylski ${ }^{1}$, Dianne Heather Vincent ${ }^{1}$, \\ Dorothy Felger $^{1}$, Douglas Jay Konersman ${ }^{1}$, Elizabeth Ann Feeney ${ }^{1}$, Jay Anthony Prague ${ }^{1}$, \\ Joanne Lydia Starodub ${ }^{1}$, Karan Rasdan ${ }^{1}$, Karen Mie Strassman ${ }^{1}$, Leonid Soboleff ${ }^{1}$, \\ Maire Anne Mayne ${ }^{1}$, Mary M. Keesee ${ }^{1}$, Padmanabha Narayana Pillai ${ }^{1}$, Pamela Clarkson Ansley ${ }^{1}$, \\ Ronald David Schmitz ${ }^{1}$, Sharyn Marie Sodomora ${ }^{1}$, Kalyan Kumar Sethi ${ }^{2}$, Parthasarathi Panda ${ }^{2}$, \\ Snehasis Jana ${ }^{2, *}$ \\ ${ }^{1}$ Trivedi Global, Inc., Henderson, Nevada, USA \\ ${ }^{2}$ Trivedi Science Research Laboratory Pvt. Ltd., Bhopal, Madhya Pradesh, India
}

Email address:

publication@trivedieffect.com (S. Jana)

${ }^{*}$ Corresponding author

To cite this article:

Mahendra Kumar Trivedi, Alice Branton, Dahryn Trivedi, Gopal Nayak, Cathryn Dawn Nykvist, Celine Lavelle, Daniel Paul Przybylski, Dianne Heather Vincent, Dorothy Felger, Douglas Jay Konersman, Elizabeth Ann Feeney, Jay Anthony Prague, Joanne Lydia Starodub, Karan Rasdan, Karen Mie Strassman, Leonid Soboleff, Maire Anne Mayne, Mary M. Keesee, Padmanabha Narayana Pillai, Pamela Clarkson Ansley, Ronald David Schmitz, Sharyn Marie Sodomora, Kalyan Kumar Sethi, Parthasarathi Panda, Snehasis Jana. Physicochemical, Thermal, Structural, and Behavioral Properties Analysis in Magnesium Gluconate: An Effect of the Energy of Consciousness (The Trivedi Effect $^{\mathbb{R}}$ ). International Journal of Biomedical Materials Research. Vol. 5, No. 2, 2017, pp. 15-24. doi: 10.11648/j.ijbmr.20170502.11

Received: January 31, 2017; Accepted: February 23, 2017; Published: March 9, 2017

\begin{abstract}
Magnesium gluconate is an organometallic pharmaceutical/nutraceutical used for the prevention and treatment of various diseases caused by the low level of magnesium. The aim of the present study was to investigate the influence of The Trivedi Effect ${ }^{\circledR}$ - Energy of Consciousness Healing Treatment (Biofield Energy Healing) on the physicochemical, thermal, structural, and behavioral properties of magnesium gluconate using powder PXRD, PSD, FT-IR, UV-visible, TGA, and DSC analysis. Magnesium gluconate was divided into two parts - one part was denoted as the control, while the another part was treated with The Trivedi Effect ${ }^{\circledR}$ remotely by eighteen renowned Biofield Energy Healers and defined as the Trivedi Effect ${ }^{\circledR}$ Treated sample. The PXRD analysis exhibited the significant alteration of the crystal morphology of the treated sample compared with the control sample. The crystallite size of the treated sample was significantly altered from $-39.99 \%$ to $62.57 \%$ compared with the control sample. The average crystallite size of the treated sample was decreased by $9.71 \%$ compared with the control sample. Particle size of the treated sample at $\mathrm{d}_{10}, \mathrm{~d}_{50}$, and $\mathrm{d}_{90}$ value was significantly increased by $5.36 \%, 23.10 \%$ and $11.11 \%$, respectively compared with the control sample. The surface area of the treated sample was significantly decreased by $9.76 \%$ compared to the control sample. The FT-IR and UV-vis analysis showed that the structural characteristic of the magnesium gluconate remained same in the treated sample compared with control sample. The TGA data revealed that the weight loss of the treated sample in the first and third steps of degradation was increased by $31.58 \%$ and $5.94 \%$, respectively, whereas in the second step of degradation, the weight loss was decreased by $7.57 \%$ compared with the control sample. The DSC analysis showed that the melting point of the control and treated samples were at $170.29^{\circ} \mathrm{C}$ and $169.76^{\circ} \mathrm{C}$, respectively. The latent heat of fusion of the treated sample was increased by $4.18 \%$ compared with the control sample. The current study evaluated that The Trivedi Effect ${ }^{\circledR}$ - Energy of Consciousness Healing Treatment might lead to a new polymorphic form of the magnesium gluconate, which could be more soluble, powder flowability and long-term storage stability compared with the control sample. Hence, the Trivedi Effect ${ }^{\circledR}$ Treated magnesium gluconate would be very useful to design better nutraceutical and/or pharmaceutical formulations that might provide better therapeutic response against inflammatory diseases,
\end{abstract}


immunological disorders, and other chronic infections.

Keywords: The Trivedi Effect ${ }^{\circledR}$, Energy of Consciousness, Biofield Energy Healers, Magnesium Gluconate, PXRD, PSD, TGA, DSC

\section{Introduction}

Magnesium ion $\left(\mathrm{Mg}^{2+}\right)$ is a major intracellular ion and plays an important role in the regulation of tRNA and rRNA structures. This ion is also a crucial cofactor for many RNA and DNA processing enzymes as well as for those enzymes using AMP, ADP, or ATP as substrates [1-3]. Hence, magnesium ion is an essential mineral element in human and animal nutrition. It is also used as a metallotherapeutic agent to treat many diseases such as asthma, arrhythmias, acute myocardial infarction, gestational hypertension, preeclampsia and eclampsia [1-8]. Perioperative magnesium supplementation is found to be very useful in the management of postoperative pain by inhibiting postoperative hypomagnesia as well as reducing the incidence of postoperative shivering $[9,10]$. Gluconic acid is a minor organic acid formed from glucose through a simple dehydrogenation reaction catalyzed by the glucose oxidase. Gluconic acid and its derivatives are commonly used in the food and pharmaceutical industry [11]. Magnesium gluconate $\left(\mathrm{MgC}_{12} \mathrm{H}_{22} \mathrm{O}_{14}\right)$ is the magnesium salt of gluconic acid. It is used by itself or in combination with one or more antioxidants for the prevention and treatment of diabetes mellitus, allergies, septic shock, inflammatory diseases, immunological disorders, and other chronic infections [12, 13]. It can be used intravenously in the treatment of ischemia/reperfusion injury due to oxidative stress in order to block free radical flow [14]. This salt is used as an oral tocolytic agent in women, whose labor is arrested initially with intravenous therapy by acting on non-selective $\beta$ receptor [15]. The scientific literature reports that magnesium gluconate is the most powerful antioxidants than other magnesium salts [12]. Moreover, magnesium gluconate is physiologically acceptable salt among other salt forms [13]. Scientific literature mentions that the bioavailability of magnesium is less in humans, because they have difficulties in absorption of magnesium through the narrow channels in their biological membranes due to the higher steric constraints for magnesium transporters and incapability of its hydration shell $[16,17]$. Magnesium gluconate showed the most magnesium absorption and highest bioavailability among the other form of magnesium salts such as chloride, sulfate, carbonate, acetate, citrate, lactate, aspartate, etc. [18]. In this point of view, a novel proprietary herbomineral formulation was designed as a nutraceutical supplement, and can be used for the prevention and treatment of various human disorders. Magnesium gluconate is one of the components in this novel proprietary herbomineral formulation as the source of magnesium ion.

Since ancient times, many different cultures, religions and systems of belief have recognized a living force that preserves and inhabits every living organism. This force is the source of 'life' and has been called various names, such as prana by the Hindus, qi or chi by the Chinese, and $k i$ by the Japanese. This is believed to co-relate with the soul, spirit and mind. This hypothetical vital force has been scientifically evaluated and is now considered the Bioenergetics Field. The Biofield Energy is a dynamic electromagnetic field surrounding the human body, resulting from the continuous emission of low-level light, heat, and acoustical energy from the body. Biofield Energy is infinite, paradimensional and can freely flow between the human and environment $[19,20]$. So, a human has the ability to harness energy from the ionosphere of the earth, the "universal energy field", and transmit it to any living organism(s) or nonliving object(s) around the globe. The object or recipient always receives the energy and responds in a useful way. This process is known as The Trivedi Effect ${ }^{\circledR}$ - Biofield Energy Healing Treatment [21]. Biofield (Putative Energy Field) based Energy Therapies are used worldwide to promote health and healing. The National Center of Complementary and Integrative Health $(\mathrm{NCCIH})$ has recognized and accepted Biofield Energy Healing as a Complementary and Alternative Medicine (CAM) health care approach in addition to other therapies, medicines and practices such as natural products, deep breathing, yoga, Tai Chi, Qi Gong, chiropractic/osteopathic manipulation, meditation, massage, special diets, homeopathy, progressive relaxation, guided imagery, acupressure, acupuncture, relaxation techniques, hypnotherapy, healing touch, movement therapy, pilates, rolfing structural integration, mindfulness, Ayurvedic medicine, traditional Chinese herbs and medicines, naturopathy, essential oils, aromatherapy, Reiki, cranial sacral therapy and applied prayer (as is common in all religions, like Christianity, Hinduism, Buddhism and Judaism) [22]. The Biofield Energy Healing Treatment (The Trivedi Effect $\left.{ }^{(}\right)$has been published in numerous peerreviewed science journals due to its significant impacts in the science fields of biotechnology, genetics, cancer, microbiology, materials science, agriculture, and pharmaceuticals. These publications reported that the Biofield Energy Treatment (The Trivedi Effect ${ }^{\circledR}$ ) has the astounding capability to transform the physical, structural, chemical, thermal and behavioral properties of several pharmaceuticals [23-25], nutraceuticals [26, 27], organic compounds [28-30], metals and ceramic in materials science [31-33], and improve the overall productivity of crops [3436 ] as well as to modulate the efficacy of the various living cells [37-40]. Although magnesium gluconate exhibits the highest bioavailability and moderate solubility in water in comparison to other magnesium salts, humans still face problems in achieving their daily requirements of magnesium 
[41]. The physical and chemical properties such as particle size, crystalline structure, crystallite size, surface area, etc. of a pharmaceutical have a direct influence on the absorption, dissolution, and bioavailability of the drug [42]. The stability of a solid drug with respect to the atmospheric conditions is very important to the pharmaceutical industry during processing, formulation, storage, and packaging in order to achieve better therapeutic efficacy [43]. Biofield Energy Treatment (The Trivedi Effect ${ }^{\circledR}$ ) has been reported to change the particle/crystallite size, specific surface area, chemical and thermal behavior of an atom/ion through the possible mediation of neutrinos [44]. By considering these aspects, the physicochemical, structural, thermal and behavioral properties of the Biofield Energy Treated and the untreated magnesium gluconate were studied using various analytical techniques including powder X-ray diffraction (PXRD), particle size distribution (PSD) analysis, Fourier transform infrared (FT-IR) spectrometry, ultraviolet-visible (UV-vis) spectroscopy, thermogravimetric analysis (TGA), and differential scanning calorimetry (DSC).

\section{Materials and Methods}

\subsection{Chemicals and Reagents}

Magnesium gluconate hydrate was procured from Tokyo Chemical Industry Co., Ltd. (TCI), Japan. All other chemicals used in the experiment were of analytical grade available in India.

\subsection{Biofield Energy Healing Treatment Strategies}

Magnesium gluconate hydrate was one of the components of the new proprietary herbomineral formulation, which was developed by our research team and was used per se as the test compound for the current study. The test compound was divided into two parts, one part of the test compound was treated with the Trivedi Effect ${ }^{\circledR}$ by eighteen renowned Biofield Energy Healers and defined as the Trivedi Effect ${ }^{\circledR}$ Treated magnesium gluconate, while the second part of the test compound did not receive any sort of treatment and defined as untreated or control magnesium gluconate sample. The Trivedi Effect ${ }^{\circledR}$ Treatment was provided by the group of eighteen renowned Biofield Energy Healers, who participated in this study and performed The Trivedi Effect ${ }^{\circledR}$ - Energy of Consciousness Healing Treatment remotely to the test compound. Eleven Biofield Energy Healers were remotely located in the U.S.A., four remotely located in Canada, one each of the Biofield Energy Healer remotely located in Ireland, United Kingdom, and Russia, performed the Trivedi Effect ${ }^{\circledR}$ Treatment remotely to the test compound, while the test compound was located in the research laboratory of GVK Biosciences Pvt. Ltd., Hyderabad, India. This Biofield Treatment was provided for 5 minutes through the Healer's Unique Energy Transmission process remotely to the test compound, which was kept under laboratory conditions. None of the Biofield Energy Healers in this study visited the laboratory in person, nor had any contact with the compounds. Similarly, the control compound was subjected to "sham" healers for 5 minutes, under the same laboratory conditions. The sham healer did not have any knowledge about the Biofield Energy Treatment. After that, the Biofield Energy Treated and the untreated samples were kept in similar sealed conditions and were characterized thoroughly by PXRD, PSD, FT-IR, UV-visible spectroscopy, TGA, and DSC analysis.

\subsection{Characterization}

\subsubsection{Powder X-ray Diffraction (PXRD) Analysis}

The XRD analysis was performed on PANalytical X'pert Pro powder X-ray diffractometer system. The control and Biofield Energy Treated samples were prepared taking 500.15 and $500.18 \mathrm{mg}$ respectively. The X-ray of wavelength $1.54056 \AA$ was used. The data was collected in the form of a chart of the Bragg angle (2 $\theta)$ vs. intensity, and a detailed table containing information on peak intensity counts, $d$ value $(\AA)$, relative intensity (\%), full width half maximum (FWHM) $\left(\theta^{\circ}\right)$. From the XRD results, the crystallite size $(\mathrm{G})$ was calculated using $\mathrm{X}$ 'pert data collector and $\mathrm{X}$ 'pert high score plus processing software. The average size of crystallite $(\mathrm{G})$ was calculated from the Scherrer equation [45]. The method was based on the width of the diffraction patterns obtained in the X-ray reflected the crystalline region. The average size of the crystallite $(\mathrm{G})$ was calculated by using the following equation 1 :

$$
\mathrm{G}=\mathrm{k} \lambda /(\mathrm{b} \operatorname{Cos} \theta)
$$

Where, $\mathrm{k}$ is the equipment constant $(0.5), \lambda$ is the $\mathrm{X}$-ray wavelength $(0.154 \mathrm{~nm})$; $\mathrm{b}$ in radians is the full-width at half of the peaks and $\theta$ the corresponding Bragg angle.

Percent change in crystallite size $(G)$ was calculated using the following equation 2 :

$$
\% \text { change in crystallite size }=\frac{\left[\mathrm{G}_{\text {Treated }}-\mathrm{G}_{\text {Control }}\right]}{\mathrm{G}_{\text {Control }}} \times 100
$$

Where, $G_{c}$ and $G_{t}$ denote the crystallite size of the control and Biofield Energy Treated samples, respectively.

\subsubsection{Particle Size Distribution (PSD) Analysis}

The average particle size and particle size distribution were analyzed using Malvern Mastersizer 2000, UK, with a detection range from $0.01 \mu \mathrm{m}$ to $3000 \mu \mathrm{m}$. The sample unit was filled with dispersant medium and operated the stirrer at $2500 \mathrm{rpm}$. Alignment of the optics was done and taken the background measurement. After the background measurement, the sample was added in to the sample unit with constant monitoring of the obscuration. When the obscuration of the sample reached in between $15 \%$ and $20 \%$, further addition of the sample stopped. When the obscuration was stable, the measurement was taken twice and the average was taken of the two measurements. The average histogram of the two measurements was recorded. The printout of the average histogram of the two measurements were documented in this study. Along with histogram, the data was presented in a table format which includes particle size $(\mu \mathrm{m})$. 
Also, the values at below $10 \%$ level $\left(\mathrm{d}_{10}\right), 50 \%$ level $\left(\mathrm{d}_{50}\right)$, and $90 \%$ level $\left(\mathrm{d}_{90}\right)$ were calculated from the histogram, and the calculations such as surface area $\left(\mathrm{m}^{2} / \mathrm{g}\right)$ were done by using Mastersizer 2000 software. Percent change in particle size (d) for at below $10 \%$ level $\left(\mathrm{d}_{10}\right), 50 \%$ level $\left(\mathrm{d}_{50}\right)$, and $90 \%$ level $\left(\mathrm{d}_{90}\right)$ was calculated using following equation 3 :

$$
\% \text { change in particle size }=\frac{\left[\mathrm{d}_{\text {Treated }}-\mathrm{d}_{\text {Control }}\right]}{\mathrm{d}_{\text {Control }}} \times 100
$$

Where, $d_{\text {Control }}$ and $d_{\text {Treated }}$ are the particle size $(\mu \mathrm{m})$ for at below $10 \%$ level $\left(\mathrm{d}_{10}\right), 50 \%$ level $\left(\mathrm{d}_{50}\right)$, and $90 \%$ level $\left(\mathrm{d}_{90}\right)$ of the control and Biofield Energy Treated samples, respectively.

Percent change in surface area (S) was calculated using following equation 4 :

$$
\left.\% \text { change in surface area }=\frac{\left[\mathrm{S}_{\text {Treated }}-\mathrm{S}_{\text {Control }}\right]}{\mathrm{S}_{\text {Control }}} \times 100\right)
$$

Where, $\mathrm{S}_{\text {Control }}$ and $\mathrm{S}_{\text {Treated }}$ are the surface area of the control and Biofield Energy Treated samples, respectively.

\subsubsection{Fourier Transform Infrared (FT-IR) Spectroscopy}

The FT-IR spectroscopy of the magnesium gluconate was performed using Spectrum Two (Perkin Elmer, USA) Fourier Transform Infrared Spectrometer with the frequency range of $400-4000 \mathrm{~cm}^{-1}$ by using pressed $\mathrm{KBr}$ disk technique.

\subsubsection{Ultraviolet-Visible (UV-Vis) Spectroscopy}

The UV-Vis spectral analysis was carried out using Shimadzu UV-2450 with UV Probe, Japan. The spectrum was recorded using $1 \mathrm{~cm}$ quartz cell with a slit width of 1.0 $\mathrm{nm}$. The wavelength ranges chosen for recording the spectra was $190-800 \mathrm{~nm}$. The absorbance spectra (in the range of 0.2 to 0.9$)$ and absorbance maximum $\left(\lambda_{\max }\right)$ were recorded.

\subsubsection{Thermogravimetric Analysis (TGA)/Differential Thermogravimetric (DTG) Analysis}

The analysis was performed using Instrument TGA Q50

$$
\% \text { change in Latent heat of fusion }=\frac{\left[\Delta \mathrm{H}_{\text {Treated }}-\Delta \mathrm{H}_{\text {Control }}\right]}{\Delta \mathrm{H}_{\text {Control }}} \times 100
$$

Where, $\Delta \mathrm{H}_{\text {Control }}$ and $\Delta \mathrm{H}_{\text {Treated }}$ are the latent heat of fusion of the control and Biofield Energy Treated samples, respectively.

\section{Results and Discussions}

\subsection{Powder X-ray Diffraction (PXRD) Analysis}

The PXRD diffractograms showed sharp and intense peaks in the control and Biofield Energy Treated magnesium gluconate and no broadening of the peaks were evident (Figure 1), which suggested that the samples are crystalline in nature. PXRD data such as the Bragg angle (20), relative
(TA Instruments, USA) thermo gravimetric analysis at a heating rate of $10^{\circ} \mathrm{C} / \mathrm{min}$ from room temperature i.e. $25^{\circ} \mathrm{C}$ to $900^{\circ} \mathrm{C}$ in a nitrogen atmosphere. A total of $9 \mathrm{mg}$ of sample was weighed in a platinum crucible. In TGA, the weight loss for each step was recorded in gram as well as in percent loss with respect to the initial weight. Also, the onset, endset, and peak temperatures for each step were recorded in TGA. In DTG, the onset, endset, peak temperature, integral area of the peak, and change in heat $(\mathrm{J} / \mathrm{g})$ of each peak were recorded. Percent change in weight loss (W) was calculated using the following equation 5:

$$
\% \text { change in weight loss }=\frac{\left[\mathrm{W}_{\text {Treated }}-\mathrm{W}_{\text {Control }}\right]}{\mathrm{W}_{\text {Control }}} \times 100
$$

Where, $\mathrm{W}_{\text {Control }}$ and $\mathrm{W}_{\text {Treated }}$ are the weight loss of the control and Biofield Energy Treated samples, respectively.

\subsubsection{Differential Scanning Calorimetry (DSC) Analysis}

The analysis was performed using the DSC Q20 (TA Instruments, USA) Differential Scanning Calorimeter. A total of $3.00 \mathrm{mg}$ of the sample was weighed and sealed in aluminum pans and equilibrated at $25^{\circ} \mathrm{C}$ and heated up to $450^{\circ} \mathrm{C}$ at the heating rate of $10^{\circ} \mathrm{C} / \mathrm{min}$ under the nitrogen gas as purge atmosphere with the flow rate of $50 \mathrm{~mL} / \mathrm{min}$. The values for onset, endset, peak temperature, peak height (mJ or $\mathrm{mW})$, peak area, and change in heat $(\mathrm{J} / \mathrm{g})$ for each peak were recorded. Percent change in melting point (T) was calculated using the following equation 6 :

$\%$ change in melting point $=\frac{\left[\mathrm{T}_{\text {Treated }}-\mathrm{T}_{\text {Control }}\right]}{\mathrm{T}_{\text {Control }}} \times 100$

Where, $\mathrm{T}_{\text {Control }}$ and $\mathrm{T}_{\text {Treated }}$ are the melting point of the control and Biofield Energy Treated samples, respectively.

\begin{tabular}{|c|c|c|c|c|c|c|c|c|c|}
\hline \multirow{2}{*}{ Entry No. } & \multicolumn{2}{|c|}{ Bragg angle $\left({ }^{\circ} 2 \theta\right)$} & \multicolumn{2}{|c|}{ Relative Intensity (\%) } & \multicolumn{2}{|c|}{ FWHM $\left({ }^{\circ} 2 \theta\right)$} & \multicolumn{3}{|c|}{ Crystallite size (G, $\mathrm{nm}$ ) } \\
\hline & Control & Treated & Control & Treated & Control & Treated & Control & Treated & \% change $^{\mathrm{a}}$ \\
\hline 1 & 5.36 & 5.35 & 100.00 & 87.75 & 0.1171 & 0.1506 & 37.63 & 29.26 & -22.24 \\
\hline
\end{tabular}

Percent change in latent heat of fusion $(\Delta \mathrm{H})$ was calculated using following equation 7 :

Table 1. PXRD data of the control and Biofield Energy Treated magnesium gluconate. 


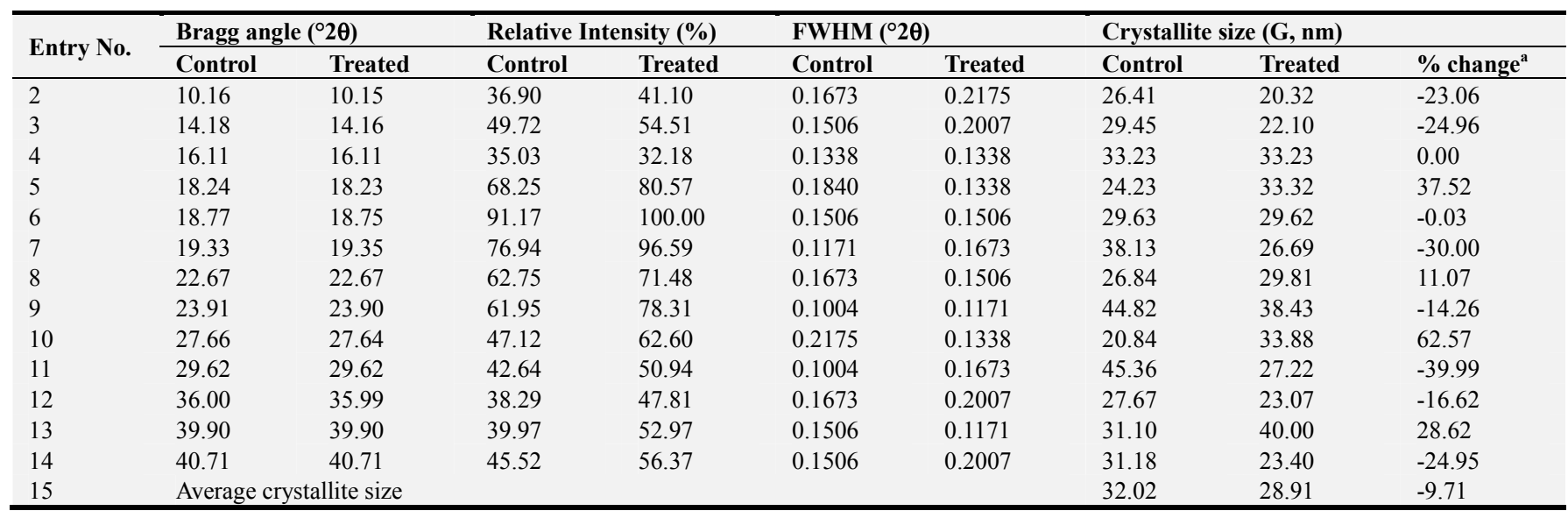

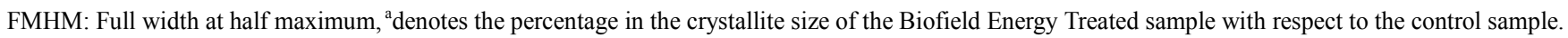

The crystallite size values of the Biofield Energy Treated sample at $2 \theta$ equal to nearly $5.4^{\circ}, 10.2^{\circ}, 14.2^{\circ}, 19.3^{\circ}, 23.9^{\circ}$, $29.6^{\circ}, 36.0^{\circ}$, and $40.7^{\circ}$ (Table 1 , entry $1-3,7,9,11,12$, and 14) were significantly decreased from $14.26 \%$ to $39.99 \%$ compared with the control sample. Consequently, the crystallite size values of the Biofield Energy Treated sample at $2 \theta$ equal to nearly $16.1^{\circ}$ and $18.8^{\circ}$ (Table 1 , entry 4 and 6) were remained unchanged compared with the control sample. The crystallite sizes of the Biofield Energy Treated sample at $2 \theta$ equal to nearly $18.2^{\circ}, 22.7^{\circ}, 27.7^{\circ}$, and $39.9^{\circ}$ (Table 1 , entry 5, 8, 10, and 13) were significantly increased from $11.07 \%$ to $62.57 \%$ compared with the control sample. The average crystallite size was significantly decreased in the Biofield Energy Treated magnesium gluconate by $9.71 \%$ as compared to the control sample.

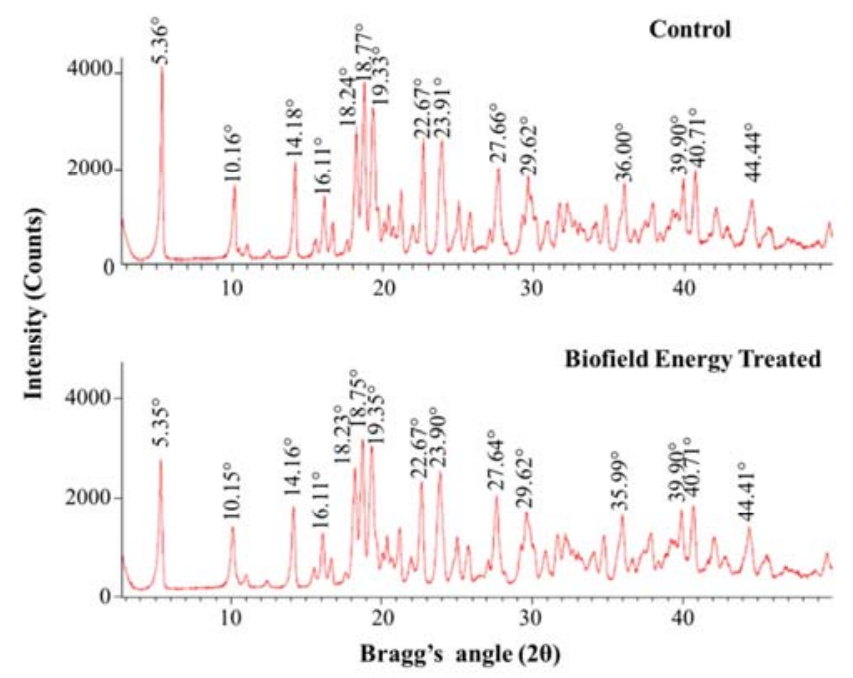

Figure 1. X-ray diffractograms of the control and Biofield Energy Treated magnesium gluconate.

It has been reported that the changes in the XRD patterns, such as crystallite size and relative intensities, indicated the modification of the crystal morphology as well as the proof of polymorphic transition [46, 47]. As the crystal morphology of the Biofield Energy Treated sample was altered compared with the control sample, the Biofield
Energy Treated sample might be a new polymorphic form of magnesium gluconate. The crystal pattern, size and even polymorphic form of a pharmaceutical play important roles in drug solubility, dissolution and bioavailability. It has been reported in the literature that the alteration in crystal morphology has significant impact on the in vitro dissolution rate, with potential for enhancing the bioavailability [43]. So, it can be concluded that the Biofield Energy Healing Treatment might be a very useful method for enhancing the bioavailability of magnesium gluconate.

\subsection{Particle Size Distribution (PSD) Analysis}

The particle size of both the control and Biofield Energy Treated magnesium gluconate were investigated, and the results are shown in Table 2. The particle size of the Biofield Energy Treated sample at $\mathrm{d}_{10}, \mathrm{~d}_{50}$, and $\mathrm{d}_{90}$ values was increased significantly by $5.36 \%, 23.10 \%$ and $11.11 \%$, respectively compared with the control sample. The surface area the control and Biofield Energy Treated sample was observed as $0.41 \mathrm{~m}^{2} / \mathrm{g}$ and $0.37 \mathrm{~m}^{2} / \mathrm{g}$, respectively (Table 2). The surface area of the Biofield Energy Treated sample was decreased by $9.76 \%$ compared to the control sample.

Table 2. Particle size data $\left(d_{10}, d_{50}\right.$ and $\left.d_{90}\right)$ and surface area of the control and Biofield Energy Treated magnesium gluconate.

\begin{tabular}{lllll}
\hline Test Item & $\mathbf{d}_{\mathbf{1 0}}(\boldsymbol{\mu \mathbf { m } )}$ & $\mathbf{d}_{\mathbf{5 0}}(\boldsymbol{\mu \mathbf { m } )}$ & $\mathbf{d}_{\mathbf{9 0}}(\boldsymbol{\mu \mathbf { m } )}$ & $\begin{array}{l}\text { Surface area } \\
\left(\mathbf{m}^{\mathbf{2}} / \mathbf{g}\right)\end{array}$ \\
\hline $\begin{array}{l}\text { Control } \\
\text { Biofield Energy }\end{array}$ & 5.97 & 32.95 & 166.68 & 0.41 \\
$\begin{array}{l}\text { Treated } \\
\text { \% change }^{\mathrm{a}}\end{array}$ & 6.29 & 40.56 & 185.20 & 0.37 \\
\hline
\end{tabular}

${ }^{\text {a }}$ denotes the percentage change in the particle size data $\left(\mathrm{d}_{10}, \mathrm{~d}_{50}\right.$, and $\left.\mathrm{d}_{90}\right)$ and surface area of the Biofield Energy Treated sample with respect to the control sample.

Particle size and the surface area have a major effect on dissolution of a compound in a solvent, because the surface energy influenced by surface area and chemical affinity is the driving factor for dissolution efficiency [48-50]. Kale et al. [51] reported that introduction of the external force leads to the transform the fine particles into larger particles. The various reasons to increase the particle size are enhanced the 
powder flowability, improved product shape and appearance [51]. It is presumed that the Biofield Energy Healing Treatment (i.e. consider as external force) might improve the powder flowability, shape and appearance of magnesium gluconate. PXRD data also supported that the Biofield Energy Healing Treatment could alter the size, shape, and appearance of magnesium gluconate.

\subsection{Fourier Transform Infrared (FT-IR) Spectroscopy}

The FT-IR spectra of the control and Biofield Energy Treated magnesium gluconate are represented in Figure 2. A broad band with high intensity in the range from 3200 to $3600 \mathrm{~cm}^{-1}$ centroid at $3398 \mathrm{~cm}^{-1}$ was observed in both spectra of the control and Biofield Energy Treated samples (Figure 2). This peak was attributed to the stretching vibrations of hydroxyl groups originating from the water present in magnesium gluconate. The bands of stretching vibrations of the primary and secondary hydroxyl groups from the gluconate part of the compound appeared in this region. These bands were remained invisible due to the intensive broad band of water [52].

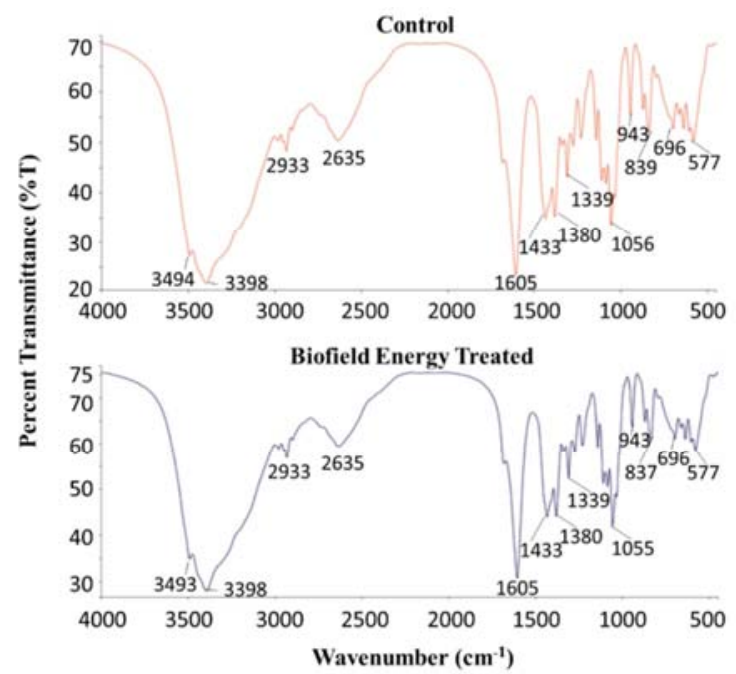

Figure 2. FT-IR spectra of the control and Biofield Energy Treated magnesium gluconate.

The absorption peaks for the deformation vibration of the hydroxyl groups in the plane $\delta(\mathrm{OH})$ and out-of-plane $\gamma(\mathrm{OH})$ that indicate the presence of primary and secondary hydroxyl groups were observed at $1433 \mathrm{~cm}^{-1}$ and $577 \mathrm{~cm}^{-1}$, respectively in the spectra of both the control and Biofield Energy Treated magnesium gluconate. The FT-IR spectra of the control and Biofield Energy Treated magnesium gluconate samples showed $\mathrm{C}-\mathrm{H}$ stretching at $2933 \mathrm{~cm}^{-1}$ and $1380 \mathrm{~cm}^{-1}$. A very sharp and intensive band at $1605 \mathrm{~cm}^{-1}$ for $\mathrm{C}=\mathrm{O}$ stretching vibration of a carbonyl group of carboxylate anion was observed in the spectra of both the control and Biofield Energy Treated magnesium gluconate. The band of the C-O stretching vibrations of the primary alcohol group was perceived at $1056 \mathrm{~cm}^{-1}$ in the spectra of both the control and Biofield Energy Treated magnesium gluconate. The FTIR analysis indicated that there was no significant alteration of the characteristic peaks for the functional groups. Hence, it can be concluded that the structure of the magnesium gluconate remained the same in both the Biofield Energy Treated and control samples.

\subsection{Ultraviolet-Visible (UV-Vis) Spectroscopy}

The UV-vis spectra of both the control and Biofield Energy Treated samples of magnesium gluconate showed that the wavelength for the maximum absorbance at $198 \mathrm{~nm}$ $\left(\lambda_{\max }\right)$ (Figure 3).

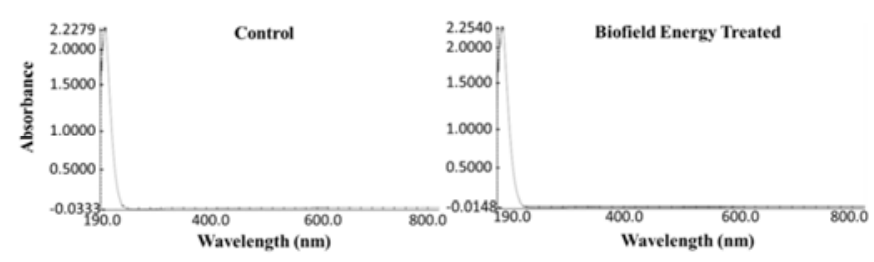

Figure 3. UV-vis spectra of the control and Biofield Energy Treated magnesium gluconate.

The peak at $198 \mathrm{~nm}$ showed a minor shift of absorbance maxima from 2.2291 in the control sample to 2.2553 in the Biofield Energy Treated sample. The UV absorbance happens due to the different types of energy transitions from the singlet to the singlet excited state such as $\sigma \rightarrow \sigma^{*}, n \rightarrow \pi^{*}$, and $\pi \rightarrow \pi^{*}$, These types of electronic transitions are occurred when the difference in energy between the lowest unoccupied molecular orbital (LUMO) and the highest occupied molecular orbital (HOMO) is significantly higher than the activation energy of the compound [53]. As there was no significant alternation in the $\lambda_{\max }$ of the Biofield Energy Treated sample compared with the control, it is inferred that the structural configuration or activation energy of the Biofield Energy Treated sample was not different from the control sample.

\subsection{Thermogravimetric Analysis (TGA)/Differential Thermogravimetric (DTG) Analysis}

The TGA thermograms of both the control and Biofield Energy Treated samples exhibited three steps of thermal degradation (Figures 4 and Table 3). The control sample lost their weight by $2.85 \%, 37.91 \%$, and $42.44 \%$ in the $1^{\text {st }}, 2^{\text {nd }}$ and $3^{\text {rd }}$ steps of degradation, respectively (Table 3 ). Similarly, the Biofield Energy Treated sample was lost weight by $3.75 \%, 35.04 \%$, and $44.96 \%$ in the $1^{\text {st }}, 2^{\text {nd }}$ and $3^{\text {rd }}$ steps of degradation, respectively (Table 3 ). The weight loss of the Biofield Energy Treated sample in the first and third steps of degradation was increased by $31.58 \%$ and $5.94 \%$, respectively, whereas in the second step of degradation, the weight loss was decreased by $7.57 \%$ compared with the control sample. The overall weight loss was $83.20 \%$ and $83.75 \%$ in the control and Biofield Energy Treated samples, respectively from their original total weight during this process (Figure 4). The total weight loss was slightly increased by $0.66 \%$ in the Biofield Energy Treated sample compared with the control sample. The DTG thermograms of the control and Biofield Energy Treated samples disclosed 
maximum temperature $\left(\mathrm{T}_{\max }\right)$ at $244.81^{\circ} \mathrm{C}$ and $243.71^{\circ} \mathrm{C}$, respectively (Figure 5). The onset degradation temperature was at $232.38^{\circ} \mathrm{C}$ for control, and $232.45^{\circ} \mathrm{C}$ for the Biofield Energy Treated sample. The end-set degradation temperature was observed at $272.12^{\circ} \mathrm{C}$ for the control sample and $276.56^{\circ} \mathrm{C}$ for the Biofield Energy Treated sample, respectively. The DTG analysis indicated that the decomposition temperature of the Biofield Energy Treated magnesium gluconate was altered compared with the control sample. Overall, TGA/DTG revealed that the weight loss of the Biofield Energy Treated magnesium gluconate and maximum temperature during the thermal degradation process were changed compared with the control sample.

Table 3. Thermal degradation steps of the control and Biofield Energy Treated magnesium gluconate.

\begin{tabular}{|c|c|c|c|c|c|}
\hline \multirow{2}{*}{ S. No. } & \multicolumn{2}{|c|}{ Temperature $\left({ }^{\circ} \mathrm{C}\right)$} & \multicolumn{2}{|c|}{$\%$ Weight loss } & \multirow{2}{*}{$\%$ Change $^{a}$} \\
\hline & Control & Treated & Control & Treated & \\
\hline $1^{\text {st }}$ step of degradation & 151.63 & 155.49 & 2.85 & 3.75 & 31.58 \\
\hline $2^{\text {nd }}$ step of degradation & 260.56 & 252.06 & 37.91 & 35.04 & -7.57 \\
\hline $3^{\text {rd }}$ step of degradation & 896.09 & 895.61 & 42.44 & 44.96 & 5.94 \\
\hline Total & & & 83.20 & 83.75 & 0.66 \\
\hline
\end{tabular}

adenotes the percentage change in the weight loss of the Biofield Energy Treated sample with respect to the control sample.
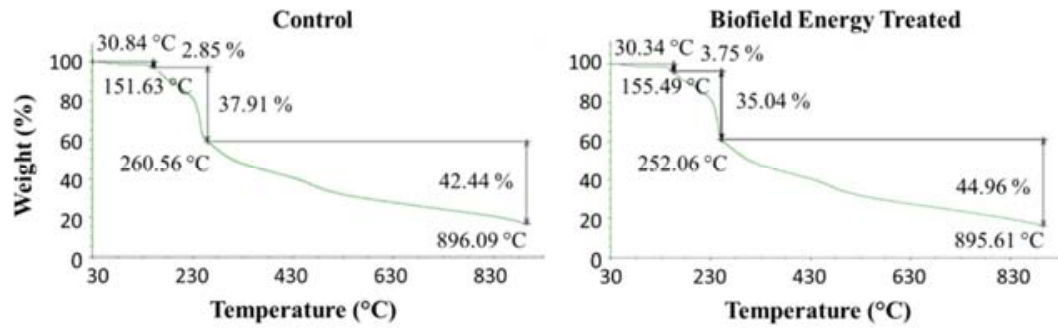

Figure 4. TGA thermograms of the control and Biofield Energy Treated magnesium gluconate.
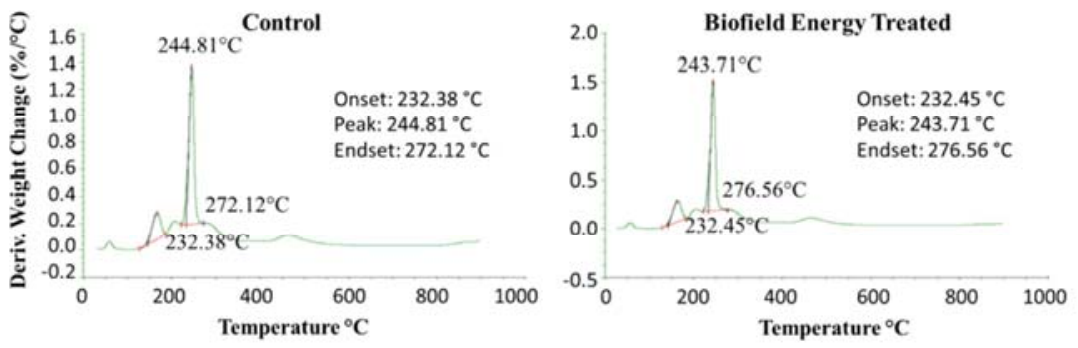

Figure 5. DTG thermograms of the control and Biofield Energy Treated magnesium gluconate.

\subsection{Differential Scanning Calorimetry (DSC) Analysis}

The DSC thermograms of the control and Biofield Energy Treated samples of magnesium gluconate are shown in Figure 6. The melting point of the Biofield Energy Treated sample $\left(170.29^{\circ} \mathrm{C}\right)$ was decreased slightly by $0.31 \%$ compared with the control sample $\left(169.76^{\circ} \mathrm{C}\right)$. The latent heat of fusion $(\Delta \mathrm{H})$ of the control and Biofield Energy Treated samples were $298.8 \mathrm{~J} / \mathrm{g}$ and $311.3 \mathrm{~J} / \mathrm{g}$, respectively. The latent heat of fusion $(\Delta \mathrm{H})$ was increased by $4.18 \%$ in the Biofield Energy Treated sample compared with the control sample. The data indicated that the Biofield Energy Treated magnesium gluconate needs more energy in the form of latent heat of fusion in order to undergo the process of melting after the Biofield Energy Treatment. It is presumed that the Biofield Energy Treatment might induce the intermolecular force in the Biofield Energy Treated magnesium gluconate, which possibly induced the heat change. It is also hypothesized that the Biofield Energy Treatment may cause emission of less energy during the phase transition from solid state to the liquid state, and that might be lead to increase in $\Delta \mathrm{H}$ in the Biofield Energy Treated sample compared with the control sample.

Table 4. The latent heat of fusion $(\mathrm{J} / \mathrm{G})$ and melting point $\left({ }^{\circ} \mathrm{C}\right)$ values of the control and Biofield Energy magnesium gluconate.

\begin{tabular}{llll}
\hline Sample & Latent heat of fusion $(\mathbf{\Delta H}) \mathbf{J} / \mathbf{g}$ & $\begin{array}{l}\text { Onset melting temperature } \\
\left(\mathbf{T}_{\text {onset }}\right){ }^{\circ} \mathbf{C}\end{array}$ & $\begin{array}{l}\text { Peak melting } \\
\text { temperature }\left(\mathbf{T}_{\text {peak }}\right){ }^{\circ} \mathbf{C}\end{array}$ \\
\hline Control & 298.80 & 159.45 & $\begin{array}{l}\text { Endset melting } \\
\text { temperature }\left(\mathbf{T}_{\text {endset }}\right){ }^{\circ} \mathbf{C}\end{array}$ \\
Biofield Energy Treated & 311.30 & 157.40 & 180.29 \\
\% Change $^{\text {a }}$ & 4.18 & -1.29 & 169.76 \\
\hline
\end{tabular}

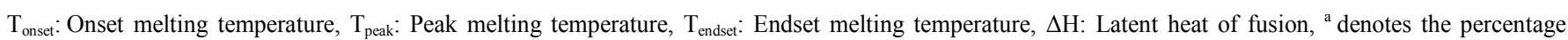
change of the Biofield Energy Treated sample with respect to the control sample. 

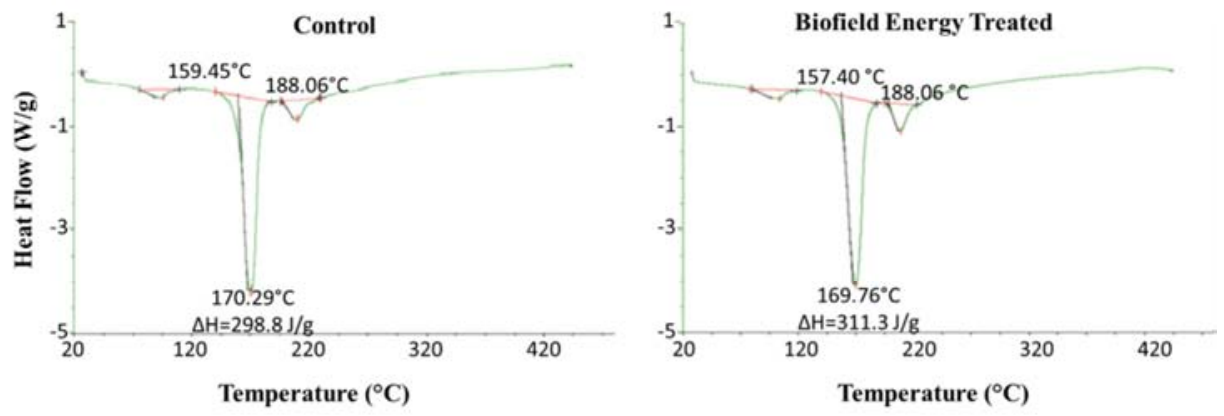

Figure 6. DSC thermograms of the control and Biofield Energy Treated magnesium gluconate.

\section{Conclusions}

The current study anticipated the notable impact of The Trivedi Effect ${ }^{\circledR}$ - Energy of Consciousness Healing Treatment on the physicochemical, thermal, structural, and behavioral properties of magnesium gluconate. The PXRD analysis exhibited that the crystallite size of the Trivedi Effect $^{\circledR}$ Energy Treated sample was significantly altered from $-39.99 \%$ to $62.57 \%$ compared with the control sample. The average crystallite size of the Biofield Energy Treated magnesium gluconate was decreased in the by $9.70 \%$ compared with the control sample. This result indicated the significant alteration of the crystal morphology of the treated sample compared with the control sample. Particle size of the treated sample at $\mathrm{d}_{10}, \mathrm{~d}_{50}$, and $\mathrm{d}_{90}$ value was significantly increased by $5.36 \%, 23.10 \%$ and $11.11 \%$, respectively compared with the control sample. The surface area of the treated sample was significantly decreased by $9.76 \%$ compared to the control sample. The TGA data revealed three steps of degradation process and the weight loss of the first and third steps of degradation in the treated sample was increased by $31.58 \%$ and $5.94 \%$, respectively, whereas in the second step of degradation, the weight loss was decreased by $7.57 \%$ compared with the control sample. The melting point of the control and treated samples were at $170.29^{\circ} \mathrm{C}$ and $169.76^{\circ} \mathrm{C}$, respectively. Consequently, the latent heat of fusion of the treated sample was increased by $4.18 \%$ compared with the control sample. Therefore, the treated magnesium gluconate would be a new polymorphic form, which might have the better powder flowability and longterm storage stability compared with the control sample. Thus, The Trivedi Effect ${ }^{\circledR}$ - Energy of Consciousness Healing Treatment, could be a useful approach in the design of better nutraceutical and/or pharmaceutical formulations that can offer significant therapeutic responses against various diseases such as diabetes mellitus, allergies and septic shock; stress-related disorders like sleep disorder, insomnia, anxiety, depression, Attention Deficit Disorder (ADD), Attention Deficit Hyperactive Disorder (ADHD), mental restlessness (mind chattering), brain frog, low libido, impotency, lack of motivation, mood swings, fear of the future, confusion, migraines, headaches, forgetfulness, overwhelm, loneliness, worthlessness, indecisiveness, frustration, irritability, chronic fatigue, obsessive/compulsive behavior and panic attacks; inflammatory diseases and immunological disorders like Lupus, Systemic Lupus Erythematosus, Hashimoto Thyroiditis, Type 1 Diabetes, Asthma, Chronic peptic ulcers, Tuberculosis, Hepatitis, Chronic active hepatitis, Celiac Disease (gluten-sensitive enteropathy), Addison Disease, Crohn's disease, Graves' Disease, Pernicious and Aplastic Anemia, Sjogren Syndrome, Irritable Bowel Syndrome (IBS), Multiple Sclerosis, Rheumatoid arthritis, Chronic periodontitis, Ulcerative colitis, Chronic sinusitis, Myasthenia Gravis, Atherosclerosis, Vasculitis, Dermatitis, Diverticulitis, Rheumatoid Arthritis, Reactive Arthritis, Alopecia Areata, Psoriasis, Scleroderma, Fibromyalgia, Chronic Fatigue Syndrome and Vitiligo; aging-related diseases like cardiovascular disease, arthritis, cancer, Alzheimer's disease, dementia, cataracts, osteoporosis, diabetes, hypertension, glaucoma, hearing loss, Parkinson's Disease, Huntington's Disease, Prion Disease, Motor Neurone Disease, Spinocerebellar Ataxia, Spinal muscular atrophy, Amyotrophic lateral sclerosis, Friedreich's Ataxia and Lewy Body Disease; chronic infections and much more.

\section{Abbreviations}

DSC: Differential scanning calorimetry, FT-IR: Fourier transform infrared spectroscopy, FWHM: Full width half maximum, G: Crystallite size, HOMO: Highest energy occupied molecular orbital, LUMO: Lowest energy unoccupied molecular orbital, TGA: Thermal gravimetric analysis, $\mathrm{T}_{\text {onset }}$ : Onset melting temperature, $\mathrm{T}_{\text {peak }}$ : Peak melting temperature, $\mathrm{T}_{\text {endset }}$ : Endset melting temperature, $\Delta \mathrm{H}$ : Latent heat of fusion, UV-vis: Ultraviolet-visible spectroscopy, PSD: Particle size distribution; PXRD: Powder $\mathrm{X}$-ray diffraction.

\section{Acknowledgements}

The authors are grateful to GVK Biosciences Pvt. Ltd., Trivedi Science, Trivedi Global, Inc. and Trivedi Master Wellness for their assistance and support during this work.

\section{References}

[1] Swaminathan R (2003) Magnesium metabolism and its disorders. Clin Biochem Rev 24: 47-66. 
[2] Ronconi L, Sadler PJ (2008) Applications of heteronuclear NMR spectroscopy in biological and medicinal inorganic chemistry. Coordn Chem Rev 252: 2239-2277.

[3] Trivedi MK, Tallapragada RM, Branton A, Trivedi D, Nayak G, Latiyal O, Jana S (2015) Potential impact of biofield treatment on atomic and physical characteristics of magnesium. Vitam Miner 3: 129.

[4] Guerrera MP, Volpe SL, Mao JJ (2009) Therapeutic uses of magnesium. Am Fam Physician 80: 157-162.

[5] Gums JG (2004) Magnesium in cardiovascular and other disorders. Am J Health Syst Pharm 61: 1569-1576.

[6] Purvis JR, Movahed A (1992) Magnesium disorders and cardiovascular diseases. Clin Cardiol 5: 556-568.

[7] Sales CH, Pedrosa Lde F (2006) Magnesium and diabetes mellitus: Their relation. Clin Nutr 25: 554-562.

[8] Nageris BI, Ulanovski D, Attias J (2004) Magnesium treatment for sudden hearing loss. Ann Otol Rhinol Laryngol 113: 672-675.

[9] Lysakowski C, Dumont L, Czarnetzki C, Tramer MR (2007) Magnesium as an adjuvant to postoperative analgesia: A systematic review of randomized trials. Anesth Analg 104: 1532-1539.

[10] Murphy JD, Paskaradevan J, Eisler LL, Ouanes JP, Tomas VA, Freck EA, Wu CL (2013) Analgesic efficacy of continuous intravenous magnesium infusion as an adjuvant to morphine for postoperative analgesia: A systematic review and metaanalysis. Middle East J Anaesthesiol 22: 11-20.

[11] Ramachandran S, Fontanille P, Pandey A, Larroche C (2006) Gluconic acid: Properties, applications and microbial production. Food Technol Biotechnol 44: 185-195.

[12] Fleming TE, Mansmann Jr HC (1999) Methods and compositions for the prevention and treatment of diabetes mellitus. United States Patent 5871769, 1-10.

[13] Fleming TE, Mansmann Jr HC (1999) Methods and compositions for the prevention and treatment of immunological disorders, inflammatory diseases and infections. United States Patent 5939394, 1-11.

[14] Weglicki WB (2000) Intravenous magnesium gluconate for treatment of conditions caused by excessive oxidative stress due to free radical distribution. United States Patent 6100297, $1-6$.

[15] Martin RW, Martin JN Jr, Pryor JA, Gaddy DK, Wiser WL, Morrison JC (1988) Comparison of oral ritodrine and magnesium gluconate for ambulatory tocolysis. Am J Obstet Gynecol 158: 1440-1445.

[16] Jahnen-Dechent W, Ketteler M (2012) Magnesium basics. Clin Kidney J 5: i3-i14.

[17] Fine KD, Ana CAS, Porter JL, Fordtran JS (1991) Intestinal absorption of magnesium from food and supplements. J Clin Invest 88: 396-402.

[18] Coudray C, Rambeau M, Feillet-Coudray C, Gueux E, Tressol JC, Mazur A, Rayssiguier Y (2005) Study of magnesium bioavailability from ten organic and inorganic $\mathrm{Mg}$ salts in $\mathrm{Mg}$ depleted rats using a stable isotope approach. Magnes Res 18: 215-223.
[19] Stenger VJ (1999) Bioenergetic fields. Sci Rev Alternative Med 3.

[20] Rogers, M (1989) "Nursing: A Science of Unitary Human Beings." In J. P. Riehl-Sisca (ed.) Conceptual Models for Nursing Practice. $3^{\text {rd }}$ edition. Norwark: Appleton \& Lange.

[21] Warber SL, Cornelio D, Straughn, J, Kile G (2004) Biofield energy healing from the inside. J Altern Complement Med 10: 1107-1113.

[22] Koithan M (2009) Introducing complementary and alternative therapies. J Nurse Pract 5: 18-20.

[23] Trivedi MK, Patil S, Shettigar H, Singh R, Jana S (2015) An impact of biofield treatment on spectroscopic characterization of pharmaceutical compounds. Mod Chem Appl 3: 159.

[24] Trivedi MK, Branton A, Trivedi D, Nayak G, Bairwa K, Jana S (2015) Spectroscopic characterization of disulfiram and nicotinic acid after biofield treatment. J Anal Bioanal Tech 6: 265.

[25] Trivedi MK, Branton A, Trivedi D, Nayak G, Singh R, Jana S (2015) Physicochemical and spectroscopic characterization of biofield treated butylated hydroxytoluene. J Food Ind Microbiol 1: 101.

[26] Trivedi MK, Tallapragada RM, Branton A, Trivedi D, Nayak G, Mishra RK, Jana S (2015) Biofield treatment: A potential strategy for modification of physical and thermal properties of gluten hydrolysate and ipomoea macroelements. J Nutr Food Sci 5: 414.

[27] Trivedi MK, Tallapragada RM, Branton A, Trivedi D, Nayak G, Latiyal O, Jana S (2015) Physical, atomic and thermal properties of biofield treated lithium powder. J Adv Chem Eng 5: 136.

[28] Trivedi MK, Branton A, Trivedi D, Nayak G, Bairwa K, Jana S (2015) Fourier transform infrared and ultraviolet-visible spectroscopic characterization of ammonium acetate and ammonium chloride: An impact of biofield treatment. Mod Chem Appl 3: 163.

[29] Trivedi MK, Branton A, Trivedi D, Nayak G, Latiyal O, Jana $S$ (2015) Evaluation of biofield treatment on atomic and thermal properties of ethanol. Organic Chem Curr Res 4:145.

[30] Trivedi MK, Branton A, Trivedi D, Nayak G, Singh R, Jana S (2016) Characterization of physical, thermal and spectroscopic properties of biofield treated ortho-toluic acid. J O Heterocyclics 106: 21-28.

[31] Trivedi MK, Tallapragada RM, Branton A, Trivedi D, Latiyal O, Jana S (2015) Influence of biofield treatment on physical and structural characteristics of barium oxide and zinc sulfide. J Laser Opt Photonics 2: 122.

[32] Trivedi MK, Nayak G, Patil S, Tallapragada RM, Latiyal O (2015) Evaluation of biofield treatment on physical, atomic and structural characteristics of manganese (II, III) oxide. J Material Sci Eng 4: 177.

[33] Trivedi MK, Nayak G, Patil S, Tallapragada RM, Latiyal O (2015) Studies of the atomic and crystalline characteristics of ceramic oxide nano powders after bio field treatment. Ind Eng Manage 4: 161.

[34] Trivedi MK, Branton A, Trivedi D, Nayak G, Bairwa K, Jana S (2015) Physical, thermal, and spectroscopic characterization of biofield energy treated murashige and skoog plant cell culture media. Cell Biology 3: 50-57. 
[35] Nayak G, Altekar N (2015) Effect of a biofield treatment on plant growth and adaptation. J Environ Health Sci 1: 1-9.

[36] Trivedi MK, Branton A, Trivedi D, Nayak G, Mondal SC, Jana S (2015) Impact of biofield energy treatment on soil fertility. Earth Sciences 4: 275-279.

[37] Trivedi MK, Branton A, Trivedi D, Nayak G, Mondal SC, Jana S (2015) Antimicrobial sensitivity, biochemical characteristics and biotyping of Staphylococcus saprophyticus: An impact of biofield energy treatment. J Women's Health Care 4: 271.

[38] Trivedi MK, Branton A, Trivedi D, Nayak G, Gangwar M, Jana S (2015) Use of energy healing medicine against Escherichia coli for antimicrobial susceptibility, biochemical reaction and biotyping. American Journal of Bioscience and Bioengineering 3: 99-105.

[39] Trivedi MK, Branton A, Trivedi D, Shettigar H, Nayak G, Mondal SC, Jana S (2015) Phenotyping and genotyping characterization of Proteus vulgaris after biofield treatment. International Journal of Genetics and Genomics 3: 66-73.

[40] Trivedi MK, Patil S, Shettigar H, Gangwar M, Jana S (2015) In vitro evaluation of biofield treatment on cancer biomarkers involved in endometrial and prostate cancer cell lines. J Cancer Sci Ther 7: 253-257.

[41] Ranade VV, Somberg JC (2001) Bioavailability and pharmacokinetics of magnesium after administration of magnesium salts to humans. Am J Ther 8: 345-357.

[42] Chereson R (2009) Bioavailability, bioequivalence, and drug selection. In: Makoid CM, Vuchetich PJ, Banakar UV (eds) Basic pharmacokinetics $\left(1^{\text {st }}\right.$ Edn) Pharmaceutical Press, London.

[43] Blagden N, de Matas M, Gavan PT, York P (2007) Crystal engineering of active pharmaceutical ingredients to improve solubility and dissolution rates. Adv Drug Deliv Rev 59: 617630 .
[44] Trivedi MK, Mohan TRR (2016) Biofield energy signals, energy transmission and neutrinos. American Journal of Modern Physics 5: 172-176.

[45] Langford JI, Wilson AJC (1978) Scherrer after sixty years: A survey and some new results in the determination of crystallite size. J Appl Cryst 11: 102-113.

[46] Inoue M, Hirasawa I (2013) The relationship between crystal morphology and XRD peak intensity on $\mathrm{CaSO}_{4} \cdot 2 \mathrm{H}_{2} \mathrm{O}$. J Crystal Growth 380: 169-175.

[47] Raza K, Kumar P, Ratan S, Malik R, Arora S (2014) Polymorphism: The phenomenon affecting the performance of drugs. SOJ Pharm Pharm Sci 1: 10.

[48] http://www.dissolution.com/ddg/showthread.php?2366Surface-Area- $v s$-Particle-Size

[49] Mosharrof M, Nyström C (1995) The effect of particle size and shape on the surface specific dissolution rate of microsized practically insoluble drugs. Int J Pharm 122: 3547.

[50] Martin AN, Patrick JS (2006) Martin's physical pharmacy and pharmaceutical sciences: Physical chemical and biopharmaceutical principles in the pharmaceutical sciences. Phila: Lippincott Williams and Wilkins.

[51] Kale VV, Gadekar S, Ittadwar AM (2011) Particle size enlargement: Making and understanding of the behavior of powder (particle) system. Syst Rev Pharm 2: 79.

[52] Nikolić VD, Ilić DP, Nikolić, LB, Stanojević, LP, Cakić MD, Tačić AD, Ilić-Stojanović SS (2014) The synthesis and characterization of iron (II) gluconate. Advanced technologies 3: 16-24.

[53] Hesse M, Meier H, Zeeh B (1997) Spectroscopic methods in organic chemistry, Georg Thieme Verlag Stuttgart, New York. 